\title{
Comparing Outgoing Female CEOs With Prior CEO Experience To Outgoing Female CEOs With No Prior CEO Experience
}

Eahab Elsaid, University of Windsor, Canada

\begin{abstract}
It is difficult for females to climb the corporate ladder to the CEO position. Most of the previous research examines the obstacles that prevent females from reaching top management positions and ultimately the top position of CEO. In this study we examine this issue from the opposite side, i.e., we examine CEO successions were the outgoing CEO is female and the incoming CEO is male. We distinguish between outgoing female CEO successors who have prior CEO experience and those who do not have prior CEO experience. We find that prior CEO experience is positively related to the outgoing female CEO total compensation in the year preceding the succession, positively related to firm performance and negatively related to the probability of firm bankruptcy in the three years preceding the succession. Prior CEO experience is also positively related to the percentage of female and ethnic minority directors on the board in the two years preceding the succession.
\end{abstract}

Keywords: Female CEO; Prior CEO Experience; Firm Performance; Probability of Bankruptcy; Board Diversity

\section{INTRODUCTION}

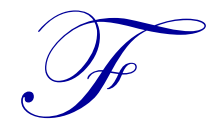

annie Hurst, an American novelist who passed away in 1968, once said, "A woman has to be twice as good as a man to go half as far." This appears to be the case today when it comes to females in CEO positions. In 2013, women accounted for about $4 \%$ of CEOs in Fortune 500 companies, according to advocacy group Catalyst ${ }^{1}$. In 2012, there were only 18 female CEOs of Fortune 500 companies (Aguilar, 2013). This was an increase from the 8 female CEOs of Fortune 500 companies in 2005 (Catalyst, 2006). However, when females do get a chance to serve in leadership positions (Ryan and Haslam, 2007; 2005) they are faced with the "glass cliff" phenomenon ${ }^{2}$. The "glass cliff" phenomenon states that females are overrepresented in precarious leadership positions (Ryan and Haslam, 2009; 2005). Haslam and Ryan (2008) go as far as stating that "women are selected for leadership positions ahead of similarly qualified men when (and only when) there is a high risk of organizational failure."

\section{Female CEOs}

There are several explanations for the low numbers of female CEOs and females in top management positions in general. One of the reasons is the exit of highly capable females from the male-dominated corporate world in order to start their own businesses (Oakley, 2000). In 1992, there were 6.5 million female-owned businesses that employed more individuals than all the Fortune 500 firms combined (Rosener, 1995). From 1975 to 1990, female entrepreneurs in the U.S. started businesses at a rate that was more than twice as much as their male counterparts (Moore and Buttner, 1997).

\footnotetext{
${ }^{1}$ Catalyst is a research organization specializing in female's career advancement.

${ }^{2}$ The "glass cliff" phenomenon has been challenged by Adams, Gupta and Leeth (2009).
} 
Another possible reason for the low number of female CEOs is that females at the CEO position advocate for change from the status quo. This is a threat to the "old boy network" which is defined by Oakley (2000) as "an informal male social system that stretches within and across organizations, and excludes less powerful males and all women from membership." It has been established that female CEOs and females in top management positions in general are paid less than their male counterparts (Kulich et al., 2011; Blau and Khan, 2000; Roos and Gatta, 1999; Gordon, 1992). As a result, allowing large numbers of females to advance to CEO positions can be seen as a threat to the ever increasing compensation packages and perks that most CEOs currently enjoy and that have been criticized by the media and the general public (Byrne, 1996). This is one of the areas where the effect of the "old boy network" is apparent since CEO compensation is determined by the board of directors which usually includes CEOs of other firms who are appointed by the CEO himself.

\section{Lack of Fit Stereotype}

There seems to be a lack of fit stereotype when it comes to female CEOs. This stems from the "thinkmanager-think-male" paradigm. Females are stereotyped as being communal, as in having warm and soft traits (Kulich et al., 2011). These qualities, while positive in general, are not valued in a managerial context where agentic qualities, such as the ability to implement change and exert influence are more valuable (Kulich et al., 2011). Female CEOs are stereotyped as being less emotionally stable, less influential, less self-confident, less consistent, less analytical, and possessing poorer leadership traits than their male counterparts (Heilman and Haynes, 2005; Oakley, 2000; Eagly, Makhijani and Klonsky, 1992; Heilman et al., 1989). It is no surprise that female CEOs and top corporate managers strive to conform to male stereotype traits such as competence and the ability to influence (Schein, 2001; Offermann and Beil, 1992). The feminine leadership style includes soliciting input from others in order to create open lines of communication and make everyone feel included (Rosener, 1995; Powell, 1993; Helegesen, 1990). This willingness to share information and power could be a successful strategy for becoming a middle manager but not for advancing to the CEO position (Oakley, 2000).

However, once a female has overcome this lack of fit stereotype by holding a CEO position, this stereotype is diminished since the female CEO has proved that she can fit in and is an effective leader. This in turn makes it easier for a female with prior CEO experience to get hired as CEO again without having to deal with the lack of fit stereotype that first-time female CEOs have to struggle with. Hence, it would be helpful to compare female CEOs with prior CEO experience to female CEOs with no prior CEO experience.

We organize the remainder of the paper as follows. We start by reviewing past literature on CEOs with prior CEO experience. Based on the literature review, we establish three testable hypotheses. Then we discuss the sample and data followed by a discussion of our results. Finally we conclude.

\section{BACKGROUND, MOTIVATION, AND DEVELOPMENT OF HYPOTHESES}

\section{CEOs With Prior CEO Experience}

Hamori and Koyuncu (2014a, 2014b) point out an interesting new trend in CEO succession: Firms have been hiring CEOs with prior CEO experience. Prior to the 1990s, hiring CEOs with prior CEO experience represented less than $1 \%$ of new CEO hires (Karlsson and Neilson, 2009). This figure increased to about 5\% between 1995 and 2002 and increased again to about 20\% between 2007 and 2009 (Karlsson and Neilson, 2009). This dramatic increase in hiring CEOs with prior CEO experience may be due to the fact that firms are increasingly unwilling to take the risk of hiring individuals with no previous job-specific experience (Charan, 2005). Further, hiring firms assume that prior CEO experience provides both a good track record and an understanding of the CEO job (Khurana, 2001).

Besides Hamori and Koyuncu (2014a, 2014b) there has not been extensive research conducted on CEOs with prior CEO experience. Elsaid, Wang and Davidson (2011) and Graffin, Boivie and Carpenter, (2013) have compared compensation, performance and stock market reaction for firms hiring CEOs with prior CEO experience to those hiring CEOs with no prior CEO experience. To the best of our knowledge, there has been no previous 
research specifically comparing outgoing female CEOs with prior CEO experience to outgoing female CEOs with no prior CEO experience.

\section{Prior CEO Experience And CEO Compensation}

The CEO position is an example of positions where individuals develop their managerial capabilities using the learning by doing phenomenon (Kotter, 1982). It also requires managing a combination of short-term, mediumterm and long-term responsibilities for the firm (Kotter, 1982). Prior CEO experience helps form routines and decision-making shortcuts, i.e., "knowledge corridors" through which CEOs can understand and deal with the outside world (Rerup, 2005), which speeds up the decision-making process (Cormier and Hagman, 1987).

Hiring a CEO with prior CEO experience will possibly reduce the risk associated with the succession. That is to say, firms have to pay an experience premium when hiring CEOs with prior CEO experience (Sturman, Walsh and Cheramie, 2008). The prior CEO experience increases the candidate's competitive advantage (Castanias and Helfat, 1991) because it provides him/her a rare and valuable set of skills (Combs and Skill, 2003) and increases their human capital which should lead to higher pay in the labor market (Gerhart and Rynes, 2003). Thus, we hypothesize that:

Hypothesis 1: Prior CEO experience is positively related to outgoing female CEO total compensation in the year preceding the succession.

\section{Prior CEO Experience And Firm Performance}

CEO positions are radically different than other management positions because they require unique competencies such as managing the board of directors and the shareholders of the firm (McCall, 2004). The CEO position is unique in that it requires an understanding of different functional backgrounds such as, operations, sales, marketing, finance, accounting, and advertising, just to name a few. CEOs with prior CEO experience have performed a wide range of position-specific tasks and are likely to have obtained the competencies needed for this post (Hamori and Koyuncu, 2014a). CEOs with prior CEO experience usually will have a relatively shorter learning curve than their counterparts because they have transferable job-specific skills (Castanias and Helfat, 2001) that allow them to yield better performance for their firms. Previous research has suggested that job-specific skill and knowledge is a determinant of firm performance (Schmidt and Hunter, 1998). Thus, we hypothesize that:

Hypothesis 2a: Prior CEO experience is positively related to firm performance (as measured by Industry Adjusted ROA) in the three years preceding the succession.

Hypothesis 2b: Prior CEO experience is negatively related to the firm's probability of bankruptcy (as measured by Altman's Z Score) in the three years preceding the succession.

\section{Prior CEO Experience And Board Diversity}

The resource-based theory of competitive advantage (Barney, 1991; 1997; Grant 1991) can be used to understand the importance of ethnic and gender diversity on corporate boards. The resource-based theory proposes that firms have "bundles" of resources that lead to competitive advantages. The more unique and difficult to replicate these bundles of resources the stronger the firm's competitive advantage (Shrader, Blackburn and Iles, 1997). Human capital resources, such as ethnic and gender diversity, are considered to be sustainable resources that are among the most difficult to imitate and argued to be key to competitive advantage (Singh, Terjesen and Vinnicombe, 2008; Smith, Smith and Verner, 2006). Hillman, Cannella and Harris (2002) state that “... female and racial minority directors bring more resources than the additional perspectives and legitimacy provided by their gender and/or race. They bring a variety of occupational expertise and knowledge....." As a result, we believe that CEOs with prior experience realize the importance of board diversity and strive during their tenure to increase the board diversity of the firms they lead. Thus, we hypothesize that: 
Hypothesis 3: Prior CEO experience is positively related to the board of director diversity (as measured by the percentage of female and ethnic minority directors) in the two years preceding the succession.

\section{SAMPLE SELECTION AND DATA}

Our sample consists of a hand-collected dataset of CEO successions between 1996 and 2013 (Elsaid, 2014). We form our sample by searching Standard and Poor's Execucomp database for CEO successions where the predecessor CEO was a female and the successor CEO was male. Execucomp contains data about top executives and their compensation for large, small and mid cap North American firms. The final sample consists of 46 CEO successions where the predecessor CEO was a female and the successor CEO was male (Elsaid, 2014).

We obtain financial statement information from Compustat. We use the firms' proxy statements to obtain data such as size of the board of directors, CEO age, CEO tenure, and whether the predecessor female CEO has prior CEO experience (Elsaid, 2014). We also use the proxy statements to get information on the composition of the board of directors. For example, the number of female directors and the number of ethnic minority directors.

To determine the type of succession, we examine the column "REASON" in the Execucomp database, which explains why the named CEO left the company (Elsaid, 2014). It provides four different reasons: resigned, retired, deceased, or unknown ${ }^{3}$. We verified the reason listed in Execucomp by searching the Wall Street Journal Index (WSJI) and the Wall Street Journal (WSJ) for the reasons for the succession. From the news stories, we classify voluntary successions as all CEO successions arising from retirement (CEOs over age 60$)^{4}$, death, illness, or those involving the CEO's departure for a better and more prestigious position in another firm.

\section{CEO Compensation Characteristics}

We examine the various components of compensation for the outgoing female CEO for the year preceding the succession, i.e., year -1 . As a result, the compensation for the predecessor female CEO is measured in the fiscal year prior to the succession year. We ignore the transition year, i.e., year 0 , since the transition year compensation data may include partial year compensation or compensation for those individuals holding positions other than CEO within the firm during the year. In addition, transition year compensation may include departure compensation for the predecessor CEO. Total compensation includes salary, bonus, other annual compensation, restricted stock, stock options (valued using Black-Scholes), long-term incentive payout and all other compensation. Pay-at-risk compensation includes bonus, restricted stock and stock options. We adjust the compensation for inflation by using the Consumer Price Index.

\section{CEO Characteristics}

We determine whether the predecessor female CEO has prior CEO experience in another firm(s). We calculate predecessor CEO tenure as the difference between the year of the succession and the year in which the executive became CEO. We calculate the age of the predecessor CEOs as their age in the year of the succession announcement. We determine whether the successor CEO joined the company from the outside. We determine whether or not the predecessor CEO holds the title of CEO and chairman, CEO duality. CEO duality may concentrate power in the CEO's position, allowing the CEO to potentially control information available to other board members, which may impede effective monitoring (Jensen, 1993). We create an indicator variable equal to 1 if the CEO also holds the title of Chairman of the Board.

\footnotetext{
${ }^{3}$ We did not have any observations were the reason for the succession was unknown.

${ }^{4} \mathrm{We}$ consider the age 60 to be the normal retirement age for a CEO as in Parrino (1997).
} 


\section{Board Characteristics}

We use the firm's proxy statements for year -2 and year -1 to determine the composition of the board of directors. We measure the percent of female directors on the board and the percent of ethnic minority directors ${ }^{5}$ on the board. We calculate these variables as the proportion of female directors and ethnic minority directors relative to total number of directors on the board.

\section{Firm Characteristics}

We use the Compustat database to obtain data on the firm characteristics in year $-1,-2$ and -3 . We then measure the industry-adjusted ROA (Barber and Lyon, 1996), Z score and firm size. Industry adjusted performance measures have been used to capture the relative performance evaluation (Blackwell, Brickley and Weisbach, 1994; Mehran, 1995). We define the ROA as net profits divided by the book value of assets and adjust it for the industry median using four-digit SIC codes and three-digit SIC codes when there are not at least three other firms in the same four-digit SIC code. Our proxy for firm size is the natural logarithm of the book value of assets. The Z score ${ }^{6}$ measures the probability of bankruptcy, and we adopt the classic Altman (1968)'s definition to calculate it for each firm. Altman (1968) designed the Z score to forecast failure in the short term.

\section{RESULTS}

Table 1. Summary Statistics

\begin{tabular}{|c|c|c|c|c|}
\hline \multicolumn{5}{|c|}{ Panel A: Descriptive Statistics } \\
\hline & $\mathbf{N}$ & Mean & Median & Standard Deviation \\
\hline Outside Succession & 46 & 0.48 & 0.00 & 0.51 \\
\hline Forced Succession & 46 & 0.46 & 0.00 & 0.50 \\
\hline OCEO Tenure & 46 & 5.49 & 4.96 & 3.89 \\
\hline OCEO Age & 46 & 53.04 & 52.00 & 5.45 \\
\hline CEO prev. CEO experience & 45 & 0.36 & 0.00 & 0.48 \\
\hline OCEO Chair & 46 & 0.50 & 0.50 & 0.51 \\
\hline$\%$ Female Dir. $_{\mathrm{t}-1}$ & 36 & 0.24 & 0.22 & 0.13 \\
\hline$\%$ Eth. Min. Dir. $t-1$ & 36 & 0.07 & 0.00 & 0.08 \\
\hline$\%$ Female Dir. $_{\mathrm{t}-2}$ & 35 & 0.22 & 0.20 & 0.14 \\
\hline$\%$ Eth. Min. Dir. ${ }_{t-2}$ & 35 & 0.08 & 0.09 & 0.09 \\
\hline Size Adj. Salary ${ }_{\mathrm{t}-1}$ & 39 & 93.90 & 89.63 & 38.68 \\
\hline Size Adj. Total Comp. ${ }_{t-1}$ & 39 & 440.52 & 284.11 & 382.26 \\
\hline Size Adj. Pay-at-Risk $_{\mathrm{t}-1}$ & 23 & 285.14 & 162.47 & 314.29 \\
\hline Ind. Adj. ROA & 42 & 1.11 & 0.06 & 7.23 \\
\hline $\mathrm{Z} \mathrm{Score}_{\mathrm{t}-1}$ & 39 & 3.88 & 3.31 & 3.17 \\
\hline $\operatorname{Ln} \mathrm{TA}_{\mathrm{t}-1}$ & 42 & 7.04 & 6.75 & 1.95 \\
\hline Ind. Adj. ROA ${ }_{t-2}$ & 43 & 0.70 & -0.02 & 4.97 \\
\hline $\mathrm{Z} \mathrm{S}$-ore $_{\mathrm{t}-2}$ & 41 & 5.54 & 4.61 & 5.61 \\
\hline Ind. Adj. ROA ${ }_{t-3}$ & 43 & 0.86 & -0.01 & 9.92 \\
\hline$Z$ Score $_{t-3}$ & 41 & 11.73 & 5.25 & 27.76 \\
\hline Ind. Adj. ROA ${ }_{\mathrm{t}-1 \mathrm{to}-3}$ & 42 & 4.04 & -0.01 & 24.04 \\
\hline $\mathrm{Z} \mathrm{S}$ core $_{\mathrm{t}-1 \mathrm{to}-3}$ & 41 & 7.01 & 4.61 & 9.87 \\
\hline
\end{tabular}

\footnotetext{
${ }^{5}$ Hillman, Cannella and Harris (2002) differentiated between White and African-American directors. We determine ethnic minorities to be directors from any other ethnicity besides Caucasian.

${ }^{6}$ The original Z-score formula (Altman, 1968, 2000) was as follows:

$\mathrm{Z}=0.012(\mathrm{WCAP} / \mathrm{TA})+0.014(\mathrm{RE} / \mathrm{TA})+0.033(\mathrm{EBIT} / \mathrm{TA})+0.006(\mathrm{MVE} / \mathrm{BVL})+0.999(\mathrm{SALE} / \mathrm{TA})$

where: $($ WCAP/TA $)=$ Working Capital $/$ Total Assets. This ratio measures liquid assets in relation to the size of the company. $(\mathrm{RE} / \mathrm{TA})=$ Retained Earnings / Total Assets. This ratio measures profitability that reflects the company's earning power. (EBIT/TA) = Earnings Before Interest and Taxes / Total Assets. This ratio measures operating efficiency apart from tax and leveraging factors. It recognizes operating earnings as being important to long-term viability. $(\mathrm{MVE} / \mathrm{BVL})=$ Market Value of Equity / Book Value of Total Liabilities. This ratio adds market dimension that can show up security price fluctuation as a possible red flag. (SALE/TA) $=$ Sales/ Total Assets. This ratio is a standard measure for sales turnover.
} 
(Table 1 continued)

\begin{tabular}{lcc}
\hline Panel B: Successions by Year & & Percent \\
\hline Year & Freq. & 2.2 \\
\hline 1996 & 1 & 6.5 \\
1997 & 3 & 2.2 \\
1998 & 1 & 0.0 \\
1999 & 0 & 6.5 \\
2000 & 3 & 0.0 \\
2001 & 0 & 4.3 \\
2002 & 2 & 6.5 \\
2003 & 3 & 2.2 \\
2004 & 1 & 6.5 \\
2005 & 3 & 21.7 \\
2006 & 10 & 4.3 \\
2007 & 2 & 8.7 \\
2008 & 4 & 6.5 \\
2009 & 3 & 4.3 \\
2010 & 2 & 6.5 \\
2011 & 3 & 8.7 \\
2012 & 4 & 2.2 \\
Total & 1 & $\mathbf{1 0 0 . 0 0}$ \\
\hline
\end{tabular}

Panel C: Successions by Fama and French (1997) 17 Industry Classification

\begin{tabular}{lcc}
\hline \multicolumn{1}{c}{ Fama-French (17) Industry } & Frequency & Percent \\
\hline Food & 1 & 2.2 \\
Mining and Minerals & 1 & 2.2 \\
Oil and Petroleum Products & 0 & 0.0 \\
Textiles, Apparel \& Footware & 2 & 4.3 \\
Consumer Durables & 1 & 2.2 \\
Chemicals & 0 & 0.0 \\
Drugs, Soap, Perfumes, Tobacco & 4 & 8.7 \\
Construction and Construction Materials & 1 & 2.2 \\
Steel Works Etc & 2 & 4.3 \\
Fabricated Products & 1 & 2.2 \\
Machinery and Business Equipment & 4 & 8.7 \\
Automobiles & 0 & 0.0 \\
Transportation & 0 & 0.0 \\
Utilities & 2 & 4.3 \\
Retail Stores & 7 & 15.2 \\
Banks, Insurance Companies, \& Other Fin. & 4 & 8.7 \\
Other & 16 & 34.8 \\
Total & $\mathbf{4 6}$ & $\mathbf{1 0 0 . 0 0}$ \\
\hline
\end{tabular}

Table 1, includes the summary statistics for our sample. Panel A provides descriptive statistics. Panel B provides a breakdown of successions by year. Panel $\mathrm{C}$ provides a breakdown of the industries in our sample by the 17 Fama and French (1997) industry classifications. In Panel C, we notice that $15.2 \%$ of our sample is retail stores where females are more likely to be hired as CEO in the case of an outside succession or advance to the CEO position in the case of an inside succession. We can consider retail to be what is referred to as a female friendly industry as compared to other industries such as oil and gas and till very recently the automotive industry ${ }^{7}$.

\footnotetext{
${ }^{7}$ On January $15^{\text {th }}$, 2014 Mary Barra became the first female to hold the CEO position at a global automaker, General Motors.
} 
Table 2. Prior CEO Experience and CEO Compensation

\begin{tabular}{lccc}
\hline & $\begin{array}{c}\text { Size Adj. Total Comp. } \mathbf{t - 1} \\
(\mathbf{1})\end{array}$ & $\begin{array}{c}\text { Size Adj. Salary } \mathbf{t - 1} \\
(\mathbf{2})\end{array}$ & $\begin{array}{c}\text { Size Adj. Pay-at-Risk } \\
\mathbf{t}-\mathbf{1}\end{array}$ \\
\hline \multirow{2}{*}{ Constant } & 291.255 & -64.608 & 550.349 \\
& $(0.477)$ & $(-1.060)$ & $(0.636)$ \\
CEO Previous CEO Experience & 216.087 & 7.684 & -23.042 \\
& $(1.726)^{*}$ & $(0.614)$ & $(-0.108)$ \\
OCEO Age & -1.790 & 2.625 & -6.732 \\
& $(-0.160)$ & $(2.345)^{* *}$ & $(-0.408)$ \\
OCEO Chair & 212.750 & -1.068 & 164.116 \\
& $(1.762)^{*}$ & $(-0.089)$ & $(0.957)$ \\
OCEO Tenure & 31.687 & 2.418 & 12.095 \\
& $(1.723)^{*}$ & $(1.317)$ & $(0.434)$ \\
Outside Succession & -192.972 & -1.341 & -121.344 \\
& $(-1.581)$ & $(-0.110)$ & $(-0.736)$ \\
Forced Turnover & 24.799 & 18.368 & -12.471 \\
Adjusted $\mathrm{R}^{2}$ & $(0.189)$ & $(1.402)$ & $(-0.068)$ \\
(F) & $17.8 \%$ & $6.5 \%$ & $2.7 \%$ \\
\hline
\end{tabular}

$* \mathrm{p}<0.10 ; * * \mathrm{p}<0.05 ; * * * \mathrm{p}<0.01$

Our first hypothesis is that in the year preceding the succession, prior CEO experience is positively related to outgoing female CEO total compensation. We use an ordinary least squares regression model to test this hypothesis. In regression 1 of table 2, we can see that consistent with Hypothesis 1, outgoing female CEO total compensation (size adjusted) is significantly positively related to the prior CEO experience variable in the year preceding the succession, i.e., year -1. That is to say, female CEOs with prior CEO experience will get an experience premium in their compensation. We also see that the outgoing female CEO total compensation (size adjusted) is significantly positively related to the outgoing female CEO tenure and whether or not the outgoing female CEO held the Chair position at the time of the succession. In regressions 2 and 3 of table 2, we see that there is no significance between prior CEO experience and outgoing female CEO salary and pay-at-risk in the year preceding the succession.

Table 3. Prior CEO Experience and Firm Performance

\begin{tabular}{|c|c|c|c|c|}
\hline & $\begin{array}{l}\text { Ind. Adj. ROA t-1 } \\
\text { (1) }\end{array}$ & $\begin{array}{l}\text { Ind. Adj. ROA t-2 } \\
\text { (2) }\end{array}$ & $\begin{array}{l}\text { Ind. Adj. ROA t-3 } \\
\text { (3) }\end{array}$ & $\begin{array}{c}\text { Ind. Adj. ROA } \\
\text { (4) }\end{array}$ \\
\hline \multirow{2}{*}{ Constant } & 8.654 & -2.044 & -29.375 & -66.477 \\
\hline & $(0.708)$ & $(-0.243)$ & $(-1.765)^{*}$ & $(-1.280)$ \\
\hline \multirow{2}{*}{ CEO Previous CEO Experience } & 4.761 & 3.153 & 3.330 & 22.765 \\
\hline & $(1.925)^{*}$ & $(1.867)^{*}$ & $(1.947)^{*}$ & $(2.401)^{* *}$ \\
\hline \multirow{2}{*}{ OCEO Age } & -0.180 & 0.019 & 0.627 & 1.027 \\
\hline & $(-0.804)$ & $(0.125)$ & $(2.042)^{* *}$ & $(1.051)$ \\
\hline \multirow{2}{*}{ OCEO Chair } & -2.807 & -2.597 & -3.056 & 9.529 \\
\hline & $(-1.189)$ & $(-1.606)$ & $(-0.946)$ & $(1.220)$ \\
\hline \multirow{2}{*}{ OCEO Tenure } & -0.068 & 0.263 & 0.167 & 0.120 \\
\hline & $(-0.197)$ & $(1.108)$ & $(0.354)$ & $(0.099)$ \\
\hline \multirow{2}{*}{ Outside Succession } & 1.549 & 2.884 & -5.277 & -9.970 \\
\hline & $(0.634)$ & $(1.720)^{*}$ & $(-1.576)$ & $(-1.112)$ \\
\hline \multirow{2}{*}{ Forced Turnover } & 2.792 & -0.365 & 1.315 & 18.476 \\
\hline & $(1.055)$ & $(-0.201)$ & $(0.366)$ & $(1.994)^{*}$ \\
\hline Adjusted $\mathrm{R}^{2}$ & $4.1 \%$ & $3.1 \%$ & $3.5 \%$ & $25.1 \%$ \\
\hline$(\mathrm{F})$ & $(1.283)$ & $(1.217)$ & $(1.248)$ & (1.669) \\
\hline
\end{tabular}


Our second hypothesis is that in the three years preceding the succession, prior CEO experience is positively related to firm performance $(H 2 a)$ and negatively related to firm's probability of bankruptcy $(H 2 b)$. We use an ordinary least squares regression model to test this hypothesis. In regressions 1 to 3 of table 3 , we can see that, consistent with Hypothesis $2 a$, firm performance (as measured by Industry Adjusted ROA) is significantly positively related to the prior CEO experience variable in the three years preceding the succession, i.e., year $-1,-2$ and -3 . In regression 4 of table 3 we see that the average firm performance over the three year period preceding the succession is also significantly positively related to the prior CEO experience variable.

Table 4. Prior CEO Experience and Firm Bankruptcy

\begin{tabular}{|c|c|c|c|c|}
\hline & Z Score $_{t-1}$ & Z Score $_{t-2}$ & Z Score $_{t-3}$ & Z Score $_{t-1 t o-3}$ \\
\hline & -1.797 & 16.273 & 99.482 & 2.411 \\
\hline Constant & $(-0.379)$ & $(1.681)$ & $(2.065)^{* *}$ & $(0.132)$ \\
\hline CEO Previous CEO Experience & $\begin{array}{l}-2.210 \\
(-2.308)^{* *}\end{array}$ & $\begin{array}{l}-1.895 \\
(-1.690)^{*}\end{array}$ & $\begin{array}{l}-3.724 \\
(-2.425)^{*}\end{array}$ & $\begin{array}{l}-5.959 \\
(-1.754)^{*}\end{array}$ \\
\hline OCEO Age & $\begin{array}{c}0.120 \\
(1.358)\end{array}$ & $\begin{array}{l}-0.158 \\
(-0.876)\end{array}$ & $\begin{array}{l}-1.616 \\
(-1.799)^{*}\end{array}$ & $\begin{array}{c}0.062 \\
(0.180)\end{array}$ \\
\hline OCEO Chair & $\begin{array}{c}1.310 \\
(1.414)\end{array}$ & $\begin{array}{c}-0.365 \\
(-0.193)\end{array}$ & $\begin{array}{l}-13.201 \\
(-1.403)\end{array}$ & $\begin{array}{c}-2.189 \\
(-0.753)\end{array}$ \\
\hline OCEO Tenure & $\begin{array}{c}0.062 \\
(0.441)\end{array}$ & $\begin{array}{c}-0.127 \\
(-0.436)\end{array}$ & $\begin{array}{c}0.842 \\
(0.582)\end{array}$ & $\begin{array}{c}0.032 \\
(0.066)\end{array}$ \\
\hline Outside Succession & $\begin{array}{l}-1.150 \\
(-1.207)\end{array}$ & $\begin{array}{c}-2.529 \\
(-1.289)\end{array}$ & $\begin{array}{c}-5.318 \\
(-0.545)\end{array}$ & $\begin{array}{c}-4.284 \\
(-1.284)\end{array}$ \\
\hline Forced Turnover & $\begin{array}{c}-0.975 \\
(-0.973)\end{array}$ & $\begin{array}{c}0.569 \\
(0.280)\end{array}$ & $\begin{array}{c}-4.351 \\
(-0.429)\end{array}$ & $\begin{array}{c}-0.911 \\
(-0.271)\end{array}$ \\
\hline $\begin{array}{l}\text { Adjusted } \mathrm{R}^{2} \\
\text { (F) }\end{array}$ & $\begin{array}{l}17.8 \% \\
(2.336)^{*}\end{array}$ & $\begin{array}{l}22.6 \% \\
(2.020)\end{array}$ & $\begin{array}{l}19.7 \% \\
(1.346)\end{array}$ & $\begin{array}{l}14 \% \\
(1.301)\end{array}$ \\
\hline
\end{tabular}

$* \mathrm{p}<0.10 ; * * \mathrm{p}<0.05 ; * * * \mathrm{p}<0.01$

In regressions 1 to 3 of table 4, we can see that, consistent with Hypothesis $2 b$, the firm's probability of bankruptcy (as measured by Altman's Z Score) is significantly negatively related to the prior CEO experience variable in the three years preceding the succession, i.e., year $-1,-2$ and -3 . In regression 4 of table 4 we see that the average firm's probability of bankruptcy over the three year period preceding the succession is also significantly negatively related to the prior $\mathrm{CEO}$ experience variable.

Table 5: Prior CEO Experience and Board Diversity

\begin{tabular}{|c|c|c|c|c|}
\hline & $\begin{array}{l}\text { \% Female Dir.t-1 } \\
\text { (1) }\end{array}$ & $\begin{array}{l}\text { \% Female Dir. } t-2 \\
\text { (2) }\end{array}$ & $\begin{array}{c}\text { \% Eth. Min. Dir.t-1 } \\
\text { (3) }\end{array}$ & $\begin{array}{l}\text { \% Eth. Min. Dir. } t-2 \\
\text { (4) }\end{array}$ \\
\hline \multirow{2}{*}{ Constant } & 0.713 & 1.267 & 0.301 & 0.243 \\
\hline & $(1.420)$ & $(2.026)^{*}$ & $(1.338)$ & $(0.652)$ \\
\hline \multirow{2}{*}{ CEO Previous CEO Experience } & 0.060 & 0.059 & 0.043 & 0.055 \\
\hline & $(3.026)^{* *}$ & $(2.941)^{* *}$ & $(1.937)^{*}$ & $(2.702)^{* *}$ \\
\hline \multirow{2}{*}{ OCEO Age } & -0.014 & -0.024 & -0.005 & -0.002 \\
\hline & $(-1.389)$ & $(-1.853)^{*}$ & $(-1.125)$ & $(-0.216)$ \\
\hline \multirow{2}{*}{ OCEO Chair } & 0.017 & 0.001 & 0.027 & 0.038 \\
\hline & $(0.235)$ & $(0.013)$ & $(0.730)$ & $(0.611)$ \\
\hline \multirow{2}{*}{ OCEO Tenure } & -0.002 & 0.002 & -0.004 & 0.008 \\
\hline & $(-0.214)$ & $(0.163)$ & $(-0.745)$ & $(0.922)$ \\
\hline \multirow{2}{*}{ Outside Succession } & 0.166 & 0.137 & 0.076 & -0.009 \\
\hline & $(1.964)^{*}$ & $(1.300)$ & $(2.070)^{*}$ & $(-0.141)$ \\
\hline \multirow{2}{*}{ Forced Turnover } & 0.259 & 0.154 & 0.058 & 0.029 \\
\hline & $(3.227)^{* * *}$ & $(1.537)$ & $(1.435)$ & $(0.439)$ \\
\hline Adjusted $\mathrm{R}^{2}$ & $40.9 \%$ & $34.8 \%$ & $11.4 \%$ & $13.5 \%$ \\
\hline$(\mathrm{F})$ & $(2.125)$ & $(1.888)$ & $(1.224)$ & $(1.280)$ \\
\hline
\end{tabular}

$* \mathrm{p}<0.10 ; * * \mathrm{p}<0.05 ; * * * \mathrm{p}<0.01$

Our third hypothesis is that in the two years preceding the succession, i.e., year -1 and -2 , prior CEO experience is positively related to the board of director diversity (as measured by the percentage of female and ethnic minority directors on the board). In regressions 1 to 4 of table 5, we can see that, consistent with Hypothesis 
3 , the percentage of female directors and percentage of ethnic minority directors is significantly positively related to the prior CEO experience variable.

\section{CONCLUSION AND DISCUSSION}

In this paper, we investigate an interesting yet mostly ignored distinction between female CEOs with prior CEO experience and first time female CEOs. An implicit assumption underlying our paper is that there are significant differences between male and female CEOs and that the results of the paper would be significantly different from those obtained for CEOs in general. In making a choice to study the outgoing female CEOs, we built our study based on the data related to the years preceding the CEO succession. An underlying assumption for this choice is that the findings of our paper will be different from the findings of studies that consider the data related to the years after the appointment of female CEOs with or without prior CEO experience. Our reasoning for focusing on outgoing female CEOs is that we are attempting to capture their effect on the firms they led towards the end of their tenure.

Consistent with Hypothesis 1, we find that prior CEO experience is positively related to the outgoing female CEO total compensation in the year preceding the succession. That is to say, experienced female CEOs enjoy the experience premium in their compensation until they leave the firm. Consistent with Hypothesis $2 a$, we find that prior CEO experience is positively related to firm performance (as measured by Industry Adjusted ROA) in the three years preceding the succession. Consistent with Hypothesis $2 b$, we find that prior CEO experience is negatively related to probability of firm bankruptcy (as measured by Altman's Z score) in the three years preceding the succession. These results are an indication that the experience premium received by experienced female CEOs is well warranted. It could be argued that experienced female CEOs do a better job of running their firms than their first time female CEO counterparts.

Consistent with Hypothesis 3, we find that prior CEO experience is positively related to board diversity (as measured by the percentage of female and ethnic minority directors) in the two years preceding the succession. The prior CEO experience helps the experienced female CEOs realize the importance of board diversity as it increases their firms' competitive advantage. As a result, those experienced CEOs end up increasing the diversity of the boards of the firms they lead over their tenure.

\section{Implications}

Female CEOs have been an understudied group for one very simple reason: historically, there have not been many of them. That is the reason why our sample is somewhat small. The study examines the new and exciting issue of female CEOs with prior CEO experience. There are very few previous articles that examine the issue of CEOs with prior CEO experience (Hamori and Koyuncu, 2014a, 2014b; Graffin, Boivie and Carpenter, 2013; Elsaid, Wang and Davidson 2011). To the best of our knowledge, this is the first study to specifically address the issue of female CEOs with prior CEO experience. Firm management and board of directors should be aware that female CEOs with prior CEO experience do outperform their counterparts with no prior CEO experience. As a result, they do warrant higher compensation.

\section{Future Research}

An interesting area for future research is to examine industry differences in promoting females to the CEO position. That is to say, why are female CEOs more prevalent in certain industries? For example, we see a strong sector effect in our data with regard to the retail industry where we see a comparatively greater number of female CEOs. Another area for future research is to examine the effect of prior CEO experience in the years following the appointment of female CEOs. In addition, it would be interesting to examine whether or not female CEOs in industries where females are more prevalent than males are compensated less than female CEOs in industries where males are more prevalent than females. That is to say, is there a compensation gender-bias based on stereotyping of certain industries as women's work (Major, 1994). 


\section{Limitations}

The study covers medium and large publicly traded U.S. firms. As a result, it does not include small and privately held firms. Any classification scheme that codes CEO successions as forced or voluntary is inherently subjective in nature. It is sometimes difficult to state with absolute certainty whether a CEO succession is forced or voluntary. The sample size ${ }^{8}$ is small due to the small number of female CEOs in general.

\section{AUTHOR INFORMATON}

Eahab Elsaid received his MBA and PhD from Southern Illinois University, Carbondale, USA. He is an Associate Professor of Finance at the Odette School of Business, University of Windsor, Canada. His research interests include: CEO compensation and succession; corporate governance; board demographics; CEO gender; and board structure. He has published in Gender in Management: An International Journal, Quarterly Review of Economics \& Finance, Managerial Finance, and the Journal of Management and Governance.

\section{REFERNCES}

Adams, S., Gupta, M., \& Leeth, J. (2009). Are female executives over-represented in precarious leadership positions? British Journal of Management, 20, 1-12.

Aguilar, L. (2013). Merely cracking the glass ceiling is not enough. Luis A. Aguilar remarks at the Women's Executive Circle of New York. Retrieved from http://blogs.law.harvard.edu/corpgov/2013/05/23/merelycracking-the-glass-ceiling-is-not-enough/

Altman, E. (1968). Financial ratios, discriminant analysis and the prediction of corporate bankruptcy. The Journal of Finance, 23, 589-609.

Altman, E. (2000). Predicting financial distress of companies. Retrieved from http://pages.stern.nyu.edu/ ealtman/Zscores.pdf

Barber, B., \& Lyon, J. (1996). Detecting abnormal operating performance: the empirical power and specification of test statistics. Journal of Financial Economics, 41, 359-399.

Barney, J. (1991). Firm resources and sustained competitive advantage. Journal of Management, 17, 99-120.

Barney, J. (1997). Gaining and sustaining competitive advantage. Reading, Massachusetts: Addison Wesley.

Blackwell, D., Brickley, J., \& Weisbach, M. (1994). Accounting information and internal performance evaluation: evidence from Texas banks. Journal of Accounting and Economics, 17, 331-358.

Blau, F., \& Kahn, L. (2000). Gender differences in pay. Journal of Economic Perspectives, 14, 75-99.

Byrne, J. (1996). How high can CEO pay go? Business Week. Retrieved from http://www.businessweek.com/stories/1996-04-21/how-high-can-ceo-pay-go

Castanias, R., \& Helfat, C. (1991). Managerial resources and rents. Journal of Management, 17, 155-171.

Castanias, R., \& Helfat, C. (2001). The managerial rents model: theory and empirical analysis. Journal of Management, 27, 661-678.

Catalyst (2006). 2005 Census of women board directors of the fortune 500. New York, NY: Catalyst.

Charan, R. (2005). Ending the CEO succession crisis. Harvard Business Review, 83, 72-81.

Combs, J., \& Skill, M. (2003). Managerialist and human capital explanations for key executive pay premiums: a contingency perspective. Academy of Management Journal, 46, 63-73.

Cormier, S., \& Hagman, J. (1987). Transfer of learning: Contemporary research and applications. San Diego: Academic Press.

Eagly, A., Makhijani, M., \& Klonsky, B. (1992). Gender and the evaluation of leaders: a meta analysis. Psychological Bulletin, 111, 3-22.

Elsaid, E. (2014). Examining the effect of change in CEO gender, functional and educational background on firm performance and risk. Journal of Applied Business Research, 30, 1605-1614.

Elsaid, E., Wang, X., \& Davidson III, W. (2011). Does experience matter? CEO successions by former CEOs. Managerial Finance, 37, 915-939.

Fama, E., \& French, K. (1997). Industry costs of equity. Journal of Financial Economics, 43, 153-193.

\footnotetext{
${ }^{8}$ Including successions where the outgoing and incoming CEOs were both female would have only increased our sample size by 4 observations.
} 
Gerhart, B., \& Rynes, S. (2003). Compensation: Theory, evidence, and strategic implications. London: Sage.

Gordon, M. (1992). Discrimination at the top. Working Woman, 68-72.

Graffin, S., Boivie, S., \& Carpenter, M. (2013). Examining CEO succession and the role of heuristics in early-stage CEO evaluation. Strategic Management Journal, 34, 383-406.

Grant, R. (1991). The resource-based theory of competitive advantage: implications for strategy formulation. California Management Review, 33, 114- 135.

Hamori, M., \& Koyuncu, B. (2014a). Experience matters? The impact of prior CEO experience on firm performance. Forthcoming in Human Resource Management.

Hamori, M., \& Koyuncu, B. (2014b). The CEO experience trap. Forthcoming in MIT Sloan Management Review.

Haslam, S., \& Ryan, M. (2008). The road to the glass cliff: differences in the perceived suitability of men and women for leadership positions in succeeding and failing organizations. Leadership Quarterly, 19, 530 546.

Heilman, M., Block, C., Martell, R., \& Simon, M. (1989). Has anything changed? Current characterizations of men, women, and managers. Journal of Applied Psychology, 74, 935-942

Heilman, M., \& Haynes, M. (2005). No credit where credit is due: attributional rationalization of women's success in male-female teams. Journal of Applied Psychology, 90, 905-916.

Helgesen, S. (1990). The Female advantage: Women's ways of leadership. New York, NY: Doubleday.

Hillman, A., Cannella, A., \& Harris, I. (2002). Women and racial minorities in the boardroom: how do they differ? Journal of Management, 28, 747-63.

Jensen, M. (1993). The modern industrial revolution, exit, and the failure of internal control systems. Journal of Finance, 48, 831-880.

Karlsson, P., \& Neilson, G. (2009). CEO succession 2008: stability in the storm. Strategy + Business, 55, 1-14.

Khurana R. (2001). Finding the right CEO: why boards often make poor choices? MIT Sloan Management Review, $43,91-95$.

Kotter, J. (1982). The general managers. New York: Free Press.

Kulich, C., Trojanowski, T., Ryan, M., Haslam, S., \& Renneboog, L. (2011). Who gets the carrot and who gets the stick? Evidence of gender disparities in executive remuneration. Strategic Management Journal, 32, 301 321.

Major, B. (1994). From social inequality to personal entitlement: the role of social comparisons, legitimacy appraisals, and group membership. Advances in Experimental Social Psychology, 26, 293-355.

McCall, J. (2004). Assessing American executive compensation: a cautionary tale for Europeans. Business Ethics: A European Review, 13, 243-254.

Mehran, H. (1995). Executive compensation structure, ownership, and firm performance. Journal of Financial Economics, 38, 163-184.

Moore, D., \& Buttner, E. (1997). Women entrepreneurs: Moving beyond the glass ceiling. Thousand Oaks, CA: Sage Publications.

Oakley, J. (2000). Gender-based barriers to senior management positions: understanding the scarcity of female CEOs. Journal of Business Ethics, 27, 321-334.

Offermann, L., \& Beil, C. (1992). Achievement styles of women leaders and their peers: toward an understanding of women and leadership. Psychology of Women Quarterly, 16, 37-56.

Parrino, R. (1997). CEO turnover and outside succession: a cross-sectional analysis. Journal of Financial Economics, 46, 165-197.

Powell, G. (1993). Women and men in management. Newbury Park, CA: Sage.

Rerup, C. (2005). Learning from past experience: footnotes on mindfulness and habitual entrepreneurship. Scandinavian Journal of Management, 21, 451-472.

Roos, P., \& Gatta, M. (1999). The gender gap in earnings. In G. Powell (Eds), Handbook of Gender and Work (pp. 95-123). London: Sage.

Rosener, J. (1995). America's competitive secret: Utilizing women as a management strategy. New York: Oxford University Press.

Ryan, M., \& Haslam, S. (2005). The glass cliff: implicit theories of leadership and gender and the precariousness of women's leadership positions. In B. Schyns and J. R. Meindl (Eds), Implicit Leadership Theories: Essays and Explorations. Greenwich, CT: Information Age Publishing.

Ryan, M., \& Haslam, S. (2007). The glass cliff: exploring the dynamics surrounding the appointment of women to precarious leadership positions. Academy of Management Review, 32, 549-572. 
Ryan, M., \& Haslam, S. (2009). Glass cliffs are not so easily scaled: on the precariousness of female CEOs' positions. British Journal of Management, 20, 13-16.

Schein, V. (2001). A global look at psychological barriers to women's progress in management. Journal of Social Issues, 57, 675-688.

Schmidt, F., \& Hunter, J. (1998). The validity and utility of selection methods in personnel psychology: practical and theoretical implications of 85 years of research findings. Psychological Bulletin, 124, 262-274.

Shrader, C., Blackburn, V., \& Iles, P. (1997). Women in management and firm financial performance: an exploratory study. Journal of Managerial Issues, 9, 355-372.

Singh, V., Terjesen, S., \& Vinnicombe, S. (2008). Newly appointed directors in the boardroom: how do women and men differ? European Management Journal, 26, 48-58.

Smith, N., Smith, V., \& Verner, M. (2006). Do women in top management affect firm performance? A panel study of 2,500 Danish firms. International Journal of Productivity and Performance Management, 55, 569-593.

Sturman, M., Walsh, K., \& Cheramie, R. (2008). The value of human capital specificity versus transferability. Journal of Management, 34, 290-316. 